ISSN 0258-7122

Bangladesh J. Agril. Res. 36(2) : 205-212, June 2011

\title{
ASSESSMENT OF STORAGE LOSSES OF DIFFERENT PULSES AT FARMERS' LEVEL IN JAMALPUR REGION OF BANGLADESH
}

\author{
M. A. MANNAN $^{1}$ AND N. TARANNUM ${ }^{2}$
}

\begin{abstract}
A survey was conducted in Jamalpur region to investigate the losses of pulses during storage at farmer's level. It was observed that farmers used traditional methods for storing pulse crops. The containers, such as Jute bag with multiple (2-5) polythene lining inside (7.7\% infestation), tin container with polythene lining inside by mixing sand with pulses (8.2\% infestation), plastic container (7.8\% infestation), plastic boium (8.6\% infestation), and RC bottle $(8.4 \%$ infestation) showed better performance for storing different pulse crops. The stored pulse of these containers had below $10 \%$ infestation level at low moisture content (below 10\%) and high germination percentage (above 80\%). In the study area, minimum number of farmers $(1.81-3.45 \%)$ cultivated pulse crops since maximum arable lands were occupied by rice.
\end{abstract}

Keywords: Pulse storage practices, assessment of losses, store insect infestation.

\section{Introduction}

Cereal grains as well as pulses are usually attacked in stores by different insect pests. Some of these insect pests are carried from the fields into stores (Appert, 1987). A good percentage of infestation occurs due to unhygienic stores. Although insect pests have been a menace to stored pulses, farmers have to store for consumption and to make the seeds available for next planting season, for more profit when it is out of season and to maintain supply when adverse conditions affect yield in some years (Muir, 1994). Pulses and legumes are stored by the farmers and governmental agencies for its utilization in the off season. Post harvest damages by insects have been recognized as an increasing important constraint to pulse production (Khaire et al., 1992). Infestation of stock comes either from outside or inside where the grains are stored. The larva feeds on the endosperm and germ of the grain and finally creates irregular holes with transparent thin outer covering (Appert, 1987). Storage of food grains by the local people is mainly traditional. The traditional methods have been used for many years with little or no modification and are successful because of the application of improved methods, though unaware. The selection of a traditional storage system by the farmers is often related to local natural resources (Hall, 1970). The extent of the infestation of various insect pests is variable under different storage structure, and practices. In each stored grain, pest consumes 5-

${ }^{1}$ Senior Scientific Officer, RARS, Bangladesh Agricultural Research Institute (BARI), Hathazari, Chittagong, ${ }^{2}$ Shere-Bangla Agricultural University (SAU), Dhaka, Bangladesh. 
$7 \%$ and up to $30-50 \%$ of the grain may be damaged (Agrios, 1988 and Caswell, 1981). The investigations on the total loss caused by insect pests were, therefore, carried out in Jamalpur region to observe the impact of farmers' practices on pulse storage.

\section{Materials and Method}

A survey was carried out in Jamalpur Sadar, Sherpur Sadar, Islampur, and Melandah thanas of Jamalpur district during the period from July to October 2005. Samples were collected from the stores of 20 farmers in each thana. From each storage container, $200 \mathrm{~g}$ were taken in polythene bags with three replications. The observations on moisture content were recorded by a moisture meter. The percentage of damaged seed was ascertained individually in 100 seeds on the basis of the presence of larvae or adult hidden inside them (Singh et al., 1977). The weight loss due to insect damage was recorded as per methodology of Girish et al. (1975). The viability test for the seeds was carried out by placing 100 seeds in the petridish between the wet blotting papers, and germination was counted after four days. For pathological study, the standard blotter method (ISTA, 1976) with some modifications was used to detect the seed borne pathogens associated with the seed samples. Seed borne pathogens were detected by observing their growth characters on the incubated seeds under a stereomicroscope at $25 \mathrm{x}$ magnification following the keys outlined by Kulshrestha et al. (1976).) Temporary slides were examined and identified with the help of keys suggested by Neergaard (1979). The statistical design of the experiment was Completely Randomized Design (CRD). The data were analysed statistically (SAS, 1985) and means were separated by DMRT.

\section{Results and Discussion}

Storage practices: From Table 1, it was revealed that maximum farmers stored their pulses in tin containers (37.84\%) and jute bag (33.45\%) along with the polythene by mixing sand followed by jute bag with multiple layer of polythene (33.33\%), and plastic boium (29.54\%). A few farmers (3.89\%) mix phostoxin tabet in pulses before storage in brass container. Multiple layers of polythene were used alone $(15.33 \%)$ and in the jute bag $(33.33 \%)$ for storing pulses. The minimum farmers used berzer plastic paint contianer (1.67\%) followed by brass container with phostoxin tablet (3.89\%) and drum with single polythene (4.53\%), respectively. In most cases, farmers stored their pulses after 2-3 sun driyings.

Moisture content: In lentil, the lowest moisture content (5.5\%) was found in plastic boium and jute bag along with polythene by mixing sand followed by plastic container, RC bottle and tin container with sand. After six months of pulse storage, moisture content was maximum (14.0 -15.2\%) in the jute bag, earthen container, drum, and drum along with polythene due to moisture absorption from air. The above containers were not kept air tight properly and sand were not used 
Table 1. The percentage of moisture, infestation level, germination and weight loss in pulses at different types of storage containers.

\begin{tabular}{|c|c|c|c|c|c|c|c|c|c|c|c|c|c|}
\hline \multirow{2}{*}{$\begin{array}{l}\text { Storage } \\
\text { containers }\end{array}$} & \multirow{2}{*}{$\begin{array}{c}\text { Structured } \\
\text { used }(\%)\end{array}$} & \multicolumn{3}{|c|}{$\%$ moisture } & \multicolumn{3}{|c|}{$\%$ infestation of grain } & \multicolumn{3}{|c|}{$\%$ germination } & \multicolumn{3}{|c|}{$\%$ weight loss } \\
\hline & & Lentil & Khesari & $\begin{array}{l}\text { Black } \\
\text { gram }\end{array}$ & Lentil & Khesari & $\begin{array}{l}\text { Black } \\
\text { gram }\end{array}$ & Lentil & Khesari & $\begin{array}{l}\text { Black } \\
\text { gram }\end{array}$ & Lentil & Khesari & $\begin{array}{l}\text { Black } \\
\text { gram }\end{array}$ \\
\hline Tin container & $13.36 \mathrm{c}$ & $11.1 \mathrm{be}$ & $12.2 \mathrm{fg}$ & 8.9 hi & $13.0 \mathrm{abc}$ & $14.2 \mathrm{~b}$ & $11.3 \mathrm{de}$ & $59.2 \mathrm{f}$ & $70.5 \mathrm{de}$ & 69.3 cde & $15.6 \mathrm{~g}$ & $18.3 \mathrm{gh}$ & $21.3 \mathrm{bc}$ \\
\hline $\begin{array}{l}\text { Tin container } \\
+1 \text { polythene }\end{array}$ & $12.36 \mathrm{c}$ & $11.2 \mathrm{bc}$ & $9.3 \mathrm{i}$ & $8.5 \mathrm{i}$ & $11.1 \mathrm{ef}$ & $13.0 \mathrm{c}$ & $12.0 \mathrm{~cd}$ & 70.7de & $77.4 \mathrm{~b}$ & $80.6 \mathrm{abc}$ & $4.71 \mathrm{~m}$ & $11.0 \mathrm{k}$ & $13.1 \mathrm{ef}$ \\
\hline $\begin{array}{l}\text { Tin container } \\
+1 \text { polythene } \\
+ \text { sand }\end{array}$ & $37.84 \mathrm{a}$ & $8.9 \mathrm{de}$ & $9.6 \mathrm{hi}$ & $9.4 \mathrm{hi}$ & $8.6 \mathrm{ij}$ & $9.3 \mathrm{fg}$ & $8.2 \mathrm{~h}$ & $82.1 \mathrm{~b}$ & $81.7 \mathrm{~b}$ & $81.0 \mathrm{ab}$ & $9.2 \mathrm{k}$ & $10.8 \mathrm{k}$ & $12.3 \mathrm{efg}$ \\
\hline Synthetic bag & $11.54 \mathrm{c}$ & $11.2 \mathrm{bc}$ & $14.9 \mathrm{bc}$ & $13.1 \mathrm{~cd}$ & $12.6 \mathrm{bcd}$ & $13.1 \mathrm{c}$ & $12.1 \mathrm{~cd}$ & $53.4 \mathrm{~g}$ & $56.0 \mathrm{~h}$ & $74.0 \mathrm{bcd}$ & $12.1 \mathrm{i}$ & $12.9 \mathrm{j}$ & $23.1 \mathrm{~b}$ \\
\hline $\begin{array}{l}2-4 \\
\text { Polythene } \\
\text { bag }\end{array}$ & $15.33 \mathrm{c}$ & $11.9 \mathrm{~b}$ & $14.2 \mathrm{c}$ & $9.1 \mathrm{hi}$ & $11.0 \mathrm{ef}$ & $10.7 \mathrm{de}$ & $11.1 \mathrm{de}$ & $71.8 \mathrm{~d}$ & $55.6 \mathrm{~h}$ & $69.3 \mathrm{de}$ & $23.7 \mathrm{c}$ & $20.2 \mathrm{de}$ & $7.4 \mathrm{~h}$ \\
\hline Jute bag & $9.53 \mathrm{~d}$ & $15.2 \mathrm{a}$ & $16.2 \mathrm{a}$ & $17.9 \mathrm{a}$ & $13.8 \mathrm{a}$ & $15.7 \mathrm{a}$ & $13.7 \mathrm{a}$ & $34.00 \mathrm{i}$ & $37.0 \mathrm{i}$ & $47.6 \mathrm{f}$ & $28.3 \mathrm{a}$ & $27.3 \mathrm{a}$ & $26.3 \mathrm{a}$ \\
\hline $\begin{array}{l}\text { Jute bag }+2- \\
5 \text { Polythene }\end{array}$ & $33.33 \mathrm{ab}$ & $11.1 \mathrm{bc}$ & $10.3 \mathrm{~h}$ & $15.9 \mathrm{~b}$ & $10.3 \mathrm{fgh}$ & $10.4 \mathrm{de}$ & $7.7 \mathrm{~h}$ & $70.2 \mathrm{de}$ & $59.1 \mathrm{gh}$ & $90.3 \mathrm{a}$ & $27.3 \mathrm{~b}$ & $17.4 \mathrm{~h}$ & $9.9 \mathrm{~g}$ \\
\hline $\begin{array}{l}\text { Jute bag }+1 \\
\text { polythene }+ \\
\text { Sand }\end{array}$ & $33.45 \mathrm{ab}$ & $5.5 \mathrm{f}$ & $9.1 \mathrm{i}$ & $6.3 \mathrm{j}$ & $8.7 \mathrm{ij}$ & $8.3 \mathrm{~h}$ & $8.4 \mathrm{~h}$ & $93.5 \mathrm{ab}$ & $88.3 \mathrm{ab}$ & $83.3 \mathrm{ab}$ & $3.9 \mathrm{mn}$ & 8.01 & $4.8 \mathrm{i}$ \\
\hline $\begin{array}{l}\text { Earthen } \\
\text { container }\end{array}$ & $11.23 \mathrm{c}$ & $14.0 \mathrm{a}$ & $10.4 \mathrm{~h}$ & 11.0 ef & $13.5 \mathrm{ab}$ & $15.1 \mathrm{a}$ & $13.2 \mathrm{ab}$ & $62.3 \mathrm{f}$ & $64.3 \mathrm{fg}$ & $66.0 \mathrm{de}$ & $21.0 \mathrm{~d}$ & $20.1 \mathrm{de}$ & $11.4 \mathrm{fg}$ \\
\hline $\begin{array}{l}\text { Earthen } \\
\text { container + } \\
\text { Sand }\end{array}$ & $18.75 \mathrm{bc}$ & $11.5 \mathrm{~b}$ & $12.8 \mathrm{def}$ & $14.2 \mathrm{c}$ & $12.9 \mathrm{abc}$ & $10.4 \mathrm{de}$ & $11.3 \mathrm{de}$ & $63.1 \mathrm{f}$ & $66.6 \mathrm{def}$ & $69.4 \mathrm{de}$ & $18.3 \mathrm{e}$ & $24.1 \mathrm{~b}$ & $17.1 \mathrm{~d}$ \\
\hline
\end{tabular}




\section{Table 1. Cont'd}

\begin{tabular}{|c|c|c|c|c|c|c|c|c|c|c|c|c|c|}
\hline \multirow{2}{*}{$\begin{array}{l}\text { Storage } \\
\text { containers }\end{array}$} & \multirow{2}{*}{$\begin{array}{l}\text { Structured } \\
\text { used }(\%)\end{array}$} & \multicolumn{3}{|c|}{$\%$ moisture } & \multicolumn{3}{|c|}{$\%$ infestation of grain } & \multicolumn{3}{|c|}{$\%$ germination } & \multicolumn{3}{|c|}{$\%$ weight loss } \\
\hline & & Lentil & Khesari & $\begin{array}{l}\text { Black } \\
\text { gram }\end{array}$ & Lentil & Khesari & $\begin{array}{l}\text { Black } \\
\text { gram }\end{array}$ & Lentil & Khesari & $\begin{array}{l}\text { Black } \\
\text { gram }\end{array}$ & Lentil & Khesari & $\begin{array}{l}\text { Black } \\
\text { gram }\end{array}$ \\
\hline $\begin{array}{l}\text { Brass } \\
\text { container }+ \\
\text { Sand }\end{array}$ & $7.56 \mathrm{~d}$ & $10.6 \mathrm{bcd}$ & $14.5 \mathrm{c}$ & $10.0 \mathrm{fgh}$ & $11.8 \mathrm{de}$ & $9.5 \mathrm{fg}$ & $12.7 \mathrm{bc}$ & $71.0 \mathrm{de}$ & 76.3 be & $69.4 \mathrm{dc}$ & $11.6 \mathrm{i}$ & $19.0 \mathrm{efg}$ & $20.2 \mathrm{c}$ \\
\hline $\begin{array}{l}\text { Brass } \\
\text { container }+ \\
\text { Phostoxin tab. }\end{array}$ & 3.89 & $10.5 \mathrm{bcd}$ & $11.4 \mathrm{~b}$ & 10.9 efg & $10.3 \mathrm{fgh}$ & $9.4 \mathrm{fg}$ & 10.7 ef & $61.4 \mathrm{f}$ & $65.6 \mathrm{def}$ & $68.6 \mathrm{de}$ & $13.1 \mathrm{~h}$ & $22.1 \mathrm{c}$ & $14.6 \mathrm{e}$ \\
\hline Drum & $7.23 \mathrm{~d}$ & $14,6 \mathrm{a}$ & $13.3 \mathrm{~d}$ & $12.0 \mathrm{de}$ & 12.8abed & $11.2 \mathrm{~d}$ & $11.9 \mathrm{~cd}$ & $64.1 \mathrm{f}$ & $65.3 \mathrm{ef}$ & $64.1 \mathrm{de}$ & $15.9 \mathrm{~g}$ & 19.6 def & $19.7 \mathrm{e}$ \\
\hline Drum+ Sand & $9.25 \mathrm{~d}$ & $10.4 \mathrm{bcd}$ & $13.0 \mathrm{def}$ & $12.9 \mathrm{~d}$ & $12.0 \mathrm{cde}$ & $13.3 \mathrm{c}$ & $11.8 \mathrm{~cd}$ & $61.0 \mathrm{f}$ & $41.3 \mathrm{i}$ & $49.4 \mathrm{f}$ & $17.3 \mathrm{f}$ & $18.6 \mathrm{fgh}$ & $22.9 \mathrm{~b}$ \\
\hline $\begin{array}{l}\text { Drum + } 1 \\
\text { Polythene }\end{array}$ & $4.53 \mathrm{e}$ & $14.1 \mathrm{a}$ & $13.3 \mathrm{~d}$ & $14.1 \mathrm{c}$ & 9.5 ghi & $14.5 \mathrm{~b}$ & $12.8 \mathrm{abc}$ & $77.0 \mathrm{c}$ & $59.6 \mathrm{gh}$ & $66.6 \mathrm{de}$ & $9.7 \mathrm{jk}$ & $14.4 \mathrm{i}$ & $21.4 \mathrm{bc}$ \\
\hline $\begin{array}{l}\text { Plastic } \\
\text { Bojum }\end{array}$ & $29.54 \mathrm{ab}$ & $5.5 \mathrm{f}$ & $6.6 \mathrm{j}$ & $6.9 \mathrm{j}$ & 8.6ij & $9.2 \mathrm{fg}$ & $9.9 \mathrm{fg}$ & $81.2 \mathrm{~b}$ & $88.2 \mathrm{ab}$ & $84.4 \mathrm{ab}$ & $\begin{array}{l}5.51 \\
\operatorname{lmn}\end{array}$ & $10.2 \mathrm{k} 1$ & $11.7 \mathrm{fg}$ \\
\hline $\begin{array}{l}\text { Plastic } \\
\text { Container }\end{array}$ & $17.33 \mathrm{bc}$ & $8.2 \mathrm{e}$ & $9.3 \mathrm{i}$ & 9.7 ghi & $8.3 \mathrm{j}$ & $8.8 \mathrm{gh}$ & $7.8 \mathrm{~h}$ & $92.4 \mathrm{ab}$ & $89.0 \mathrm{ab}$ & $83.0 \mathrm{ab}$ & $4.6 \mathrm{lmn}$ & $11.4 \mathrm{k}$ & $10.4 \mathrm{~g}$ \\
\hline Rc bottle & $8.56 \mathrm{~d}$ & $5.7 \mathrm{f}$ & $9.4 \mathrm{i}$ & 9.6hi & $8.4 \mathrm{j}$ & $10.1 \mathrm{ef}$ & $9.4 \mathrm{~g}$ & $97.7 \mathrm{a}$ & $95.0 \mathrm{a}$ & $87.3 \mathrm{a}$ & $3.9 \mathrm{mn}$ & $6.4 \mathrm{n}$ & 6.7hi \\
\hline $\begin{array}{l}\text { Berzer paint } \\
\text { container }\end{array}$ & $1.67 \mathrm{f}$ & $10.8 \mathrm{bcd}$ & $12.2 \mathrm{ef}$ & $11.2 \mathrm{ef}$ & $10.5 \mathrm{fg}$ & $11.0 \mathrm{~d}$ & $10.1 \mathrm{fg}$ & $68.7 \mathrm{de}$ & 69.0 def & 70.6 cde & $10.4 \mathrm{j}$ & $14.4 \mathrm{i}$ & $12.3 \mathrm{efg}$ \\
\hline $\begin{array}{l}\text { Level of } \\
\text { Significance }\end{array}$ & $*$ & $* *$ & $* *$ & $* *$ & $* *$ & $*$ & $*$ & $* *$ & $* *$ & $* *$ & $* *$ & $* *$ & $* *$ \\
\hline CV (\%) & 8.63 & 7.72 & 3.08 & 4.50 & 4.04 & 3.24 & 3.73 & 2.42 & 3.73 & 6.80 & 3.21 & 3.20 & 6.65 \\
\hline \multicolumn{14}{|c|}{ * Significant at $5 \%$ level } \\
\hline ** Significan & at at $1 \%$ level & & & & & & & & & & & & \\
\hline
\end{tabular}


which can absorb grain moisture. Below $10 \%$ moisture content was recorded in the the pulses stored in tin container with sand, jute bag with inside polythene lining by mixing sand, plastic boium, soyabin container and RC bottle. Same trend was observed in khesari and black gram. Singh et al. (1977) observed same moisture content in wheat regarding maximum percent (14.25) in jute bag storage.

Level of infestation and weight loss: Significant differences in the level of infestation were observed among the pulse samples stored in different containers. In lentil, lowest infestation $(8.3 \%)$ was recorded in the pulse grain stored in plastic container followed by RC bottle $(8.4 \%)$, plastic boium $(8.6 \%)$ and tin container along with the polythene by mixing sand $(8.6 \%)$. The highest infestation (13.8\%) was in jute bag followed by earthen container (13.5\%), tin container $(13.0 \%)$, earthen container with sand (12.9\%), and drum container $(12.8 \%)$. It might be due to different levels of moisture content. It is one of the important factors that directly affect seed deterioration and insect multiplication. The moisture content of the above containers was 11.1-15.2\%. Insect activity is negligible below 8-9\% moisture content (Christensen, 1972). Same trend was found in khesari and black gram. The weight loss were also minimum in lentil (3.9-5.51\%) kept in Jute bag along with polythene by mixing sand followed by plastic container, drum, tin pot with the polythene, and plastic boium.

Grain germination percentage: The viability of lentil seeds stored in RC bottle, plastic container, and jute bag with iiside polythene lining by mixing sand were significantly higher (92.4-97.7\%). The lowest (34.0\%) germination was observed in seeds stored in jute bag. The reason might be the loss of weight and infested seeds. The seeds those were low infested (8.3-8.7\%) and minimum weight loss (3.9-4.6\%) showed better germination. On the other hand, the lowest germinated $(34.00 \%)$ seeds had highest percentage of infestation (13.8\%) and weight loss (28.3\%). Same trend was observed in khesari and black gram.

From Table 2, it was observed that minimum percentage of interviewed farmers cultivate pulse crops. On an average, only from 1.81 to $3.45 \%$ farmers cultivated different pulse crops in Jamalpur region. During interviewing period, farmers were asked why they were not interested to cultivate pulse crops. Answers were as follows:

i) The maximum land were occupied by rice cultivation due to increased irrigation facilities;

ii) Farmers think that pulse crops are more risky than rice;

iii) Lack of high yielding varieties. 
Table 2. Percentage of farmers cultivated different pulse crops in Jamalpur region.

\begin{tabular}{|c|c|c|c|}
\hline \multirow{2}{*}{ Location } & \multicolumn{3}{|c|}{$\%$ farmers cultivated } \\
\hline & Lentil & Khesari & Black gram \\
\hline Jamalpur Sadar & 3.86 & 3.14 & 1.30 \\
\hline Islampur & 2.86 & 5.57 & 2.52 \\
\hline Sherpur & 4.43 & 3.14 & 2.43 \\
\hline Melandah & 2.4 & 2.0 & 1.0 \\
\hline Average & 3.39 & 3.45 & 1.81 \\
\hline
\end{tabular}

\section{Detection of fungi}

The percent moisture content of different pulses varied within the range of 14$18 \%$ (Table 3). A large number of fungi were associated with grain moldiness but the most common which were identified in the pulses during storage were Fusarium, Aspergilus, and Penicillum spp. From the results, it was revealed that significantly highest percentage of different seed borne fungal infection were recorded in black gram and lowest in lentil. This caused due to different levels of moisture content. The Fusarium spp. was found highest in black gram (9.52\%) followed by khesari (6.34\%), and lentil (4.18\%). Same trend was observed in Aspergillus and Penicillium. Christensen (1972) observed that fungi could grow and destroy many seeds stored at 10-18\% moisture content. Grain infesting insects carry spores of stored fungi.

Table 3. Germination and seed borne fungal infection recorded in different pulses.

\begin{tabular}{l|l|l|l|l|l}
\hline \multirow{2}{*}{ Pulses } & \multirow{2}{*}{$\begin{array}{c}\text { \% moisture } \\
\text { content }\end{array}$} & $\begin{array}{c}\text { Fusarium } \\
\text { spp. }\end{array}$ & $\begin{array}{c}\text { Aspergillus } \\
\text { flavus }\end{array}$ & $\begin{array}{c}\text { Aspergillus } \\
\text { niger }\end{array}$ & $\begin{array}{c}\text { Penicillium } \\
\text { spp. }\end{array}$ \\
\cline { 3 - 6 } & & 4.18 & 7.63 & 4.22 & 5.59 \\
Lentil & 15.0 & 6.34 & 16.45 & 7.62 & 8.20 \\
Khesari & 14.0 & 9.52 & 21.86 & 11.40 & 13.92 \\
\hline Blackgram & 18.0 & 1.63 & 4.58 & 0.89 & 1.95 \\
\hline
\end{tabular}

\section{Discussion}

In Jamalpur region, 19 different pulse storage practices (Table 1) were observed and some of them were proved to be better in storing pulses. The scientific basis behind these storage containers was astounding, even though the farmers do not have established scientific knowledge, but only traditional wisdom. Jute bag and tin container with the polythene lining inside by mixing sand with pulses, plastic container, and RC bottle were comparatively good storage containers. The polythene lining provides an impervious coating which would not allow even 
small insect pests. Sand mixing with the pulses may not allow the pest to survive and acts as a moisture absorber. Hall (1970) reported the admixture of wood ash or sand with food grains in many areas, usually restricted to the storage of small quantities in earthenware pots for seed purposes. Before storage in the traditional containers, pulse seeds were sun dried by the farmers. Moreover, pulses were exposed to the sun 2-3 times for 6 hours during storage and this killed most pests. Lale (1998) reported decreased oviposition and increased adult mortality of Callosobruchus maculatusin grains stored after exposure to sun. Lale and Vidal (2000) reported $100 \%$ mortality of the eggs and first instar larvae of $C$. maculates and first instar larvae of C. subinnotatus (Pie) exposed to sunlight for $2 \mathrm{~h}$ in Vigna subterranean (L.). Exposure to the sun in different coloured polythene bag for 24 h killed $C$. chinensis eggs and grubs were found in infested green gram (Singh and Sharma, 2003).

From the results, it was revealed that there was a link of stored grain pest infestation or weight loss with the moisture content of the sample. In this study, the samples which had higher moisture (14.0-15.2\%) content were more infested $(13.8 \%)$. On the other hand, the samples which contained less moisture content $(5.7 \%)$ and low infestation $(8.4 \%)$ level, showed highest potentiality of germination (97.7\%). These observations were in accordance with those of Rai and Singh (1979) who reported maximum weight loss in wheat. The views of Girish et al. (1975) also agreed that moisture content in the garin is linked with the higher pest infestation. Storage loss is directly related to structural design and structural material of stores. Under bad hygiene and in poorly designed stores, it is likely to occur considerable damage and absorption of moisture in grain would be higher. In the present study, it was easy to keep properly air tight after storing pulse seeds by the farmers in the plastic boium, plastic container (Soyabean container), and RC bottle due to its structural design.

Farmers use traditional storage containers for storing pulses for their own need only. These storage structures were comparatively cheap, ecofriendly, make use of locally available material and impart high shelf life to the stored commodities. These traditional storage systems could be applied in modem storage areas with minor modification. This could save food produces that would otherwise be damaged by insects. Rural people have knowledge on conservation and utilization of natural resources. Even though, chemical methods of management of stored produces pests are highly successful and they leave behind toxic residues. But traditional methods of storage of traditional wisdom might protect stored produces from insect infestation for considerably longer periods.

\section{References}

Agrios, C.A. 1988. Pesticide in Tropical Pest Management. Insect Science and its Application, 8: 731-736. 
Appert, J. 1987. The storage of food grains and seeds. The Tropical Agriculturist, Macmillan, London. $146 \mathrm{pp}$.

Caswell, G. H 1981. Damaged to stored cowpea in the Northern Part of Nigeria. Samaru J. Agrc. Res. 1(1): 11-19.

Christensen, C.M. 1972. Development of granary weevil and storage fungi in columns of wheat. Journal of Economic Entomology 53: 357-3 80.

Girish, G.K., S.K. Jain, A. Kumar and N.S. Agrawal. 1975. Part-V: Assessment of storage losses, quality and pesticidal contamination in wheat available in the markets of Western Uttar Pradesh and Haryana. Bulletin Grain Technology 13(1): 8-18.

Hall, D.W. 1970. Handling and storage of food grains in tropical and subtropical areas. FAO Agricultural Development Paper No. 90, Rome, Italy. ITOK., 1999. Studies on the alkaloids of Erythrima plants. Yakugaku Zasshi. 119(5): 340-3 56.

ISTA. 1976. international Rules of Seed Testing Association. Proeedings of International. Seed Tesing Association. p. 180.

Khaire, V.M., V. Kachare and U.N. Mote. 1992. Efficacy of different vegetable oils as grain protectant against pulse beetle, Callosobruchus chinensis L. in increasing storability of pigeon pea. Journal of Stored Product Research 28: 153-156.

Kulshrestha, D.D., S. B. Mathur and P. Neergaard. 1976. Identification of seed borne species of Colletrotrichum. Friesia. 11: 116-125.

Lale, N.E.S. 1998. Preliminary studies on the effect of solar heat on oviposition, development and adult mortality of the cowpea bruchid, Callosobruchus maculates (F.) in the Nigerian Savanna. Journal of Arid Environment 40(2): 157-162.

Lale, N.E.S. and S. Vidal. 2000. Mortality of different development stages of Callosobruchus maculates F. and Callosobruchus subinnotatus Pic. (Coleoptera: Bruchidae) in bambara ground nut Vigna subterranean (L.) Verdcourt seeds exposed to simulated solar heat. Zeitschrft fur Pflanzenkrankheiten und Pflanzenschutz. 107(5): 553-559.

Muir, W. E. 1994. Grain feed and crop storage. Encyclopedia of Agricultural Science 2: C-L. Academic Press. London. 486 pp.

Neergaard, P. 1979. Seed Pathology. Vol. 1. The MacMillan Press Ltd.

Rai, L. and S.N. Singh. 1979. Source of infestation and extent of loss in wheat by storage insect pests in Eastern Uttar Pradesh. Bulletin Grain Technology 17(1): 14-21.

SAS, 1985. Statistical Analysis System User's Guide, Statistics, Version 5, $1^{\text {st }}$ ed., SAS Institute, Inc., Cary, NC.

Singh, H.N., H.K. Singh and Chhoo. 1977. Estimation of losses in wheat grain by insect pests during storage in the vicinity of Varanasi. Indian J. Entomology 39(2): 158164.

Singh, S. and G. Sharma. 2003. Pulse beetle management through solar energy in stored green gram seeds. Seed Research. 31(1): 84-89. 